\title{
Bartonelosis (Carrion's Disease) in the Pediatric Population of Peru: An Overview and Update
}

Erick Huarcaya ${ }^{1}$, Ciro Maguiña ${ }^{1}$, Rita Torres $^{2}$, Joan Rupay ${ }^{1}$ and Luis Fuentes ${ }^{3}$

\begin{abstract}
Alexander von Humboldt Tropical Medical Institute, Cayetano Heredia University of Peru ${ }^{1}$, Lima, Peru; University of Illinois at Chicago, Department of Pediatrics', Chicago,U.S.; DISA Jaen, Ministry of Health ${ }^{3}$, Peru
\end{abstract}

\begin{abstract}
Bartonellosis, or Carrion's Disease, is an endemic and reemerging disease in Peru and Ecuador. Carrion's Disease constitutes a health problem in Peru because its epidemiology has been changing, and it is affecting new areas between the highland and the jungle. During the latest outbreaks, and previously in endemic areas, the pediatric population has been the most commonly affected. In the pediatric population, the acute phase symptoms are fever, anorexia, malaise, nausea and/or vomiting. The main signs are pallor, hepatomegaly, lymphadenopathies, cardiac murmur, and jaundice. Arthralgias and weight loss have also commonly been described. The morbidity and mortality of the acute phase is variable, and it is due mainly to superimposed infections or associated respiratory, cardiovascular, neurological or gastrointestinal complications. The eruptive phase, also known as Peruvian Wart, is characterized by eruptive nodes (which commonly bleed) and arthralgias. The mortality of the eruptive phase is currently extremely low. The diagnosis is still based on blood culture and direct observation of the bacilli in a blood smear. In the chronic phase, the diagnosis is based on biopsy or serologic assays. There are nationally standardized treatments for the acute phase, which consist of ciprofloxacin, and alternatively chloramphenicol plus penicillin G. However, most of the treatments are based on evidence from reported cases. During the eruptive phase the recommended treatment is rifampin, and alternatively, azithromycin or erythromycin. Key Words: Bartonellosis, Carrion's disease.
\end{abstract}

Bartonellosis, or Carrion's disease, has classically been described as an exotic disease in South America. There are a few reviews about human Bartonellosis [1-5], but some publications contain incomplete information regarding treatment or historical aspects [5]. This article is the first review that focuses on the pediatric population.

Bartonellosis has been described in Peru since the age of the pre-Columbian cultures [6,7]. The death of the Inca Huayna Capac, and of a large number of Received on 12 April 2004; revised 19 August 2004.

Address for correspondence: Dr. Ciro Maguiña Vargas, M.D. Instituto de Medicina Tropical "Alexander von Humboldt", Universidad Peruana Cayetano Heredia. Avenida Honorio Delgado 430, SMP, Lima-Peru. Phone: + (511)-4823910, Fax: + (511)-4823404.E-mail: cirom@upch,edu.pe

The Brazilian Journal of Infectious Diseases 2004;8(5):331-339 (C) 2004 by The Brazilian Journal of Infectious Diseases and Contexto Publishing. All rights reserved. inhabitants of the IncaEmpire, has been attributed to this disease. The first written report by Spanish conquerors in Ecuador dates from 1531 and the one in Peru dates from 1632 [6-9]. Carrion's Disease is the eponym in honor of the Peruvian medical student Daniel A. Carrion. He died in 1885 after two self-inoculations of an aspirate of the "Peruvian Wart" of a patient, in an attempt to describe the evolution of this disease $[4,10]$. Traditionally, Bartonellosis has been mainly reported between 500 and 3,200 meters over sea level (mosl) [11]. However, some cases have been reported at 3,500 mosl in Peru, and below 600 mosl in Ecuador $[12,13]$. The first written report of this disease was published in 1632 in Ancash, Peru [7]. Currently, Ancash is still the region with the highest incidence of Bartonellosis in Peru, followed by Cajamarca, Amazonas, the highland of Lima, and Cusco. Together, those regions have reported $95 \%$ of the cases that occurred in Peru during the last 60 years [8]. 
Although during the necropsy of Carrion there was a report of bacilli in his blood [14], it was not until 1905 that the etiologic agent was accurately described in detail by Alberto Barton [4]. The organism that causes Bartonellosis is Bartonella bacilliformis, an aerobic, pleomorphic and monopolar, flagellated Gramnegative bacterium. It is surrounded by pili and aggregative fimbriae [15]. It has a circular genome, estimated at 1,600 Kbp, in which two loci that are associated with the ability to invade erythrocytes have been identified [16,17]. Bartonella bacilliformis is characterized by being catalase, oxidase, urease and nitrate reductase negative. The members of the Bartonella genus have a fairly neutral biochemical profile, except for the production of peptidases, which varies among species [18]. Birtles et al. [19] have demonstrated that more than one genetic variant of $B$. bacilliformis has occurred during different outbreaks in Peru. This would explain the diversity in mortality and number of people affected.

Although the pathogenic factors of $B$. bacilliformis are not yet completely understood, there is evidence that the bacterium interacts with erythrocytes, using an energy dependent system. The erythrocyte membrane proteins glycophorins A and B [20,21] interact with the flagellas of the bacterium, which loosens during erythrocyte invasion [22]. Also of importance are the following proteins secreted by the bacterium: the deformin protein, which deforms the erythrocyte surface membrane without direct contact [20], and the hemolysin protein, which produces a contact-dependent hemolysis [23].

There are 20 other members of the Bartonella genus [1,24-26], which includes $B$. henselae (implicated in fever of unknown origin, Bacillary Angiomatosis, Cat Scratch Disease, Bacillary Peliosis, osteomyelitis, and other diseases), B. clarridgeiae (implicated in Cat Scratch Disease), B. quintana (implicated in Trench Fever, Bacillary Angiomatosis, asymptomatic bacteremia and endocarditis), B. grahami (implicated in neuroretinitis), and B. elizabethaea (implicated in endocarditis and neuroretinitis). Bartonella henselae and B. clarridgeiae have been found in Peru among patients with Cat Scratch Disease [27]. Other members of the genus Bartonella affect animals, and their role in human disease has not been well studied $[2,8,18,24,26]$.

The vector implicated in Bartonellosis is a female sandfly (Lutzomyiae sp.) [7,28]. Sandflies were implicated as vectors as early as 1764 [29], but this was not demonstrated until the Battistini experiment was done. Battistini collected L. verrucarum in an endemic area and was able to reproduce the disease in a Macacus rhesus monkey [4,9]. In Peru, the main vector species is L. verrucarum, which is found between $5^{\circ}$ and $13^{\circ} 13^{\prime}$ south latitude [28]. Lutzomyiae peruensis was the vector implicated in the outbreak that occurred in Cusco [30], and other species have been studied in northern Peru [31]. There is no known animal reservoir for Bartonellosis $[1,8,18]$.

\section{Epidemiology}

Bartonellosis has been described in Peru, Colombia [32] and Ecuador [12]. In Peru, the epidemiology of Bartonellosis has been changing since the last decade. New endemic areas have appeared in Cajamarca (both in San Ignacio and Jaen), in Amazonas, and in Huanuco $[1,33]$. Recently, a new endemic area known as the upper jungle, located between the highland and the jungle, has been reported in Peru [34]. During the latest outbreaks of Bartonellosis in Peru, the pediatric population has been the most affected, and has had the highest mortality rate, compared to the other age groups. In 1992, an outbreak in an Aguaruna community (natives of the upper jungle in Cajamarca-Peru) mainly affected young people and produced a mortality of $10 \%$ to $11 \%[1,8]$.

Outbreaks near sea level in Huaral, and Ica $[1,8]$, and the highlands of Cusco [35], occurred during the El Nino Southern Oscillation (ENSO) phenomenon of 1997-1998. Indeed, it has been recently demonstrated that the Carrion's Disease outbreaks that occurred in Ancash and Cusco were related to climatic factors, mainly the ENSO [36].

In a national case review done in Peru between 1945 and 1984, it was found that the most commonly 
affected group comprised patients younger than 20 years of age [37]. In a prospective study done in Ancash and Cajamarca, Solano [38] found that the most commonly affected group comprised patients between 10 and 19 years of age, followed by the group of patients between 0 and 9 years of age. In another prospective study done between 1988 and 1992 in Caraz (Ancash), Broncano and Tuya [39] found 168 patients $(65 \%)$ with the acute phase of the disease and 73 patients $(52 \%)$ with the eruptive phase of the disease. All of them were younger than 15 years old. The most commonly affected group was patients between 5 and 14 years old $(41 \%)$.

During the first reported outbreak in Cusco in 1998, $38.5 \%$ of the affected patients were between 6 and 14 years of age, and the outbreak had a total mortality of $23 \%$ [35]. The Health Ministry of Peru reported in 1999 a national incidence of 21 cases/100,000 habitants in the group younger than 4 years of age, 18 cases/ 100,000 habitants in the group between 5 and 14 years of age, 7 cases $/ 100,000$ habitants in the group between 15 and 64 years of age, and 6 cases/100,000 habitants in the group older than 64 years [8].

A cohort study, with a two-year follow-up, recently done in Ancash, found that the highest incidence of Bartonellosis occurred in patients younger than 5 years of age [40]. It was also found that $70 \%$ of the cases were concentrated among only $18 \%$ of the households in the studied region. Thus, age and a household contact with Bartonellosis were described as the best predictors for the disease.

Finally, in 2002, Rupay (unpublished data) found 632 cases of Bartonellosis in Jaen and San Ignacio (Cajamarca). Of these cases, 510 (80.7\%) were patients younger than 18 years of age and, of these pediatric patients, $274(53.7 \%)$ were males.

\section{Clinical Presentation}

Bartonella bacilliformis produces a disease known as Carrion's Disease, with two clinically distinct phases: an acute or hematic phase, known as Oroya Fever, and an eruptive or tissue phase, known as Peruvian
Wart. It was not known that the two phases were different manifestations of the same disease until the experiment done by Daniel A. Carrion in 1885 [4,14]. Any infected person can have either one or both phases, which can occur once or more than once during a lifetime $[1,8]$. Asymptomatic bacteremia has been described in ancient endemic areas, affecting $0.5 \%$ to $38.3 \%$ of the population $[13,40]$. However, in endemic areas the most common clinical presentation is the eruptive phase, which mainly affects the pediatric population $[1,8]$. In both endemic and non-endemic areas, more than $60 \%$ of the cases of the acute phase of Bartonellosis are children $[8,41]$.

The acute or hematic phase is characterized by fever. The activation of the alternative complement pathway, the increment of acute reactant proteins, and the increment of $\operatorname{IgM}$ with activation of the classic complement pathway $[42,43]$, produces a severe hemolytic anemia, evidenced by hepatosplenomegaly, pallor, and jaundice. Additionally, a transient cellular immunosuppression due to decrement and alteration in the number and function of Tlymphocytes [1-3,42], but without humoral immunodeficiency [43], predisposes the patients to superimposed infections. The mortality of the acute phase varies from $1 \%$ in hospitalized patients to $88 \%$ in untreated patients [8].

In a retrospective study done in Lima between 1976 and 1985, Espinoza [44] described 39 patients with Bartonellosis, with a mean age of 10 years (ages ranged from 2 months to 14 years). The main symptoms were fever, malaise, hyporexia, and nausea/vomiting. The most common signs were hepatomegaly, lymph node enlargement, pallor, and a systolic murmur. Laboratory data were not complete in all the patients, but 35/39 patients had severe anemia, 20/39 patients had leukocytosis, 6/29 patients had thrombocytopenia, and 4/17 patients had mild to moderate hepatic involvement. The most common complications were: neurological involvement, characterized by a decreased sensibility (6/39), meningeal signs (4/39), respiratory infections (7/39), and arthalgias (7/39).

Maguiña et al. [3] did a retrospective study between 1969 and 1992, which included 68 patients with the acute phase of Bartonellosis. Among these patients, 
$49 \%$ were younger than 14 years (mean age: 14.6 years). The most common clinical features of the acute phase were fever, malaise, anorexia, abdominal pain, arthralgias, and nausea/vomiting. Common signs of the acute phase were pallor, hepatomegaly, fever, cardiac murmur, jaundice, and lymphadenopathy. Montoya [41] found that $70 \%$ of infected children had lymph node enlargement. During the epidemic in Jaen and San Ignacio in 2002, Rupay found 399 cases of the acute phase $(78.2 \%$ of the total cases) in the pediatric population (mean age 5 years). The most common clinical presentations in his series were fever, malaise, headache and abdominal pain; and the most common signs were pallor, jaundice, and lymph node enlargement (Table 1).

Frequently, a patient with Bartonellosis will have a complication during the evolution of the disease $[1,8]$. Due to a poorly understood temporal immunosuppression, characterized by a $\mathrm{CD}_{4} / \mathrm{CD}_{8}$ inversion and complement consumption [10,45], a superimposed infection can occur. Salmonellosis sp. infection, Toxoplasmosis, Tuberculosis, reactivation of
Tuberculosis, pneumococcal pneumonia, $P$.jiroveci $(P$. carinii) pneumonia, $S$. aureus arthritis, and other infections have been described in children as a complication of Bartonellosis [1-3,8,10,11,15,41]. Non-infectious complications can also occur, and they include hyperbilirubinemia in newborns, myocarditis, pericarditis, congestive heart failure, thrombocytopenia, severe anemia, neurobartonellosis, seizures, intracranial hypertension, and multi-organ dysfunction $[1,8,41]$. Weight loss is especially common in children, and it can end up as severe malnutrition [41]. Espinoza [44] and Rupay (unpublished data) found concomitant respiratory infections as the most common pediatric complication. Maguiña et al. [3] found that nearly $70 \%$ of hospitalized patients with acute Bartonellosis had complications, with an almost equal distribution of noninfectious and infectious complications.

In 1998, during the outbreak in Cusco, Montoya [35] found that the following factors were related to mortality: age below 1 year or above 32 years, shock, $>3.7 \mathrm{mg}$ bilirubin/dL total, 12,000 leukocytes $/ \mathrm{mm}^{3}>$, and $\mathrm{a}>80 \%$ parasitic index in the blood smear.

Table 1. Clinical presentation of the acute phase of Bartonellosis (Oroya Fever)

\begin{tabular}{|c|c|c|c|c|c|}
\hline Oliveros M. et al. & $\begin{array}{c}\text { Diaz C. et al. } \\
(1955-1966) \\
(n=25)\end{array}$ & $\begin{array}{c}\text { Espinoza R. } \\
(1960-1971) \\
(n=32)\end{array}$ & $\begin{array}{c}\text { Maguiña C. } \\
(1976-1985) \\
(n=39)\end{array}$ & $\begin{array}{c}\text { Rupay J. } \\
(1969-1992) \\
(n=68)\end{array}$ & $\begin{array}{r}(2002) \\
(n=399)\end{array}$ \\
\hline \multicolumn{6}{|l|}{ Symptoms } \\
\hline Fever & $86 \%$ & $87.5 \%$ & $82 \%$ & $98.5 \%$ & $80.2 \%$ \\
\hline Hyporexia & & $53 \%$ & $61.5 \%$ & $92.6 \%$ & $21.4 \%$ \\
\hline Malaise & & $53 \%$ & $71.8 \%$ & $98.5 \%$ & $69.4 \%$ \\
\hline Nausea/vomiting & $60 \%$ & $40.5 \%$ & $53.8 \%$ & $41.2 \%$ & $49.8 \%$ \\
\hline Abdominal pain & & $20.5 \%$ & & $45.6 \%$ & $29.2 \%$ \\
\hline Arthralgias & & $9.4 \%$ & & $41.2 \%$ & $25.9 \%$ \\
\hline \multicolumn{6}{|l|}{ Signs } \\
\hline Pallor & $100 \%$ & $96.9 \%$ & $56.4 \%$ & $97.1 \%$ & $88.8 \%$ \\
\hline Hepatomegaly & $66 \%$ & $90.6 \%$ & $92.3 \%$ & $82.4 \%$ & $82.4 \%$ \\
\hline Lymph node enlargement & $65.6 \%$ & $71.8 \%$ & $69.1 \%$ & $60.7 \%$ & \\
\hline Cardiac murmur & & $59.4 \%$ & $48.7 \%$ & $77.9 \%$ & \\
\hline Jaundice & & $40.6 \%$ & & $70.6 \%$ & $21.8 \%$ \\
\hline Weight loss & & $15.6 \%$ & & & \\
\hline
\end{tabular}


Similarly, Maguiña et al. [3] found that an altered mental status (RR: 8.3, p=0.09), anasarca (RR: 32, p<0.001), or petechiae (RR: 22, $\mathrm{p}<0.05$ ), on admission were associated with mortality. In a study done between 1960 and 1971 at the Childrens Hospital in Lima, Diaz et al. [47] described the death of two out of 32 inpatients with Bartonellosis; one of them died due to congestive heart failure, and the other died due to a tonic-clonic seizure. In the early 70's, Oliveros et al. [48] did a review study that included 25 inpatients with Bartonellosis over a period of 16 years. Two of those patients died: the first one due to pneumonia and the second one due to acute renal failure. Espinoza [44] described 39 patients with Bartonellosis; of these, three died due to cerebral edema associated with meningeal signs or tonic-clonic seizures. No fatal cases have been described in the eruptive phase of Bartonellosis for many decades $[1,3,8,46]$.

During pregnancy, the acute phase of Bartonellosis produces a high mortality, both in the mother and fetus. This high mortality has been described in the offspring of pregnant women that develop the acute phase during pregnancy, even if the infection occurs in the third trimester [49]. Furthermore, trans-placental infection has been reported in a well-studied case of a 15-day old infant born in an endemic area [50], and in a oneweek old premature infant whose teenage mother had Peruvian Wart [51]. In a prospective study done in Lima, 2/5 pregnant women with the acute phase of Bartonellosis died, and 2/3 of the remaining patients had a spontaneous abortion. Among three pregnant women with the eruptive phase, none of their newborns had complications [3]. A cohort of newborns with complicated Bartonellosis was found to have a relative risk of dying of 3.36 (CI: 2.4-4.5, p<0.05) [41].

When the eruptive phase follows the acute phase, it usually does so after one to two months [4]. The pathogenesis of the eruptive phase also has not been well studied, but it is known that $B$. bacilliformis, $B$. henselae, and B. quintana produce a similar angiogenic factor [20]. Bartonella bacilliformis is efficiently internalized into endothelial cells by means of a GTPase Rho protein [20]. Peruvian Wart is characterized by angioblastic hyperplasia, loss of cell-to-cell contact, formation of stress fibers with an increase in focal contacts, activation of the Langerhans cells, IgM and IgA intra-cytoplasmic deposits, C3 complement and IgM endothelial deposits, and positive factor VIII in endothelial cells, as in Kaposi's Sarcoma [43,52,53].

Commonly, the eruptive phase adopts three patterns: a miliary eruption, with multiple and widely distributed lesions 2 to $3 \mathrm{~mm}$ in diameter; a nodular eruption, characterized by few eruptions 8 to $10 \mathrm{~mm}$ in diameter; and a "mular" eruption, a unique, large, deep-seated lesion $[1,4]$. The eruptive phase clinically resembles Kaposi's Sarcoma or Bacillary Angiomatosis [2,54,55]. Maguiña et al. [3] reported 77 patients with the eruptive phase (mean age 18.4 years). The most commonly reported symptoms of the eruptive phase were bleeding of the wart (51/77), fever (44/77), malaise (41/77), and arthralgias (36/77). The most commonly reported signs of the eruptive phase were pallor (36/77), fever (27/77), and lymphadenopathy (22/77). In 2002, during the epidemic in Cajamarca, Rupay found 111 eruptive phase cases ( $22 \%$ of the total cases). Of those, $59.5 \%$ were miliary eruptions, $30 \%$ were nodular eruptions, and $10 \%$ were mular eruptions (Table 2 ). The eruptive phase has a low morbidity and there are no reports of mortality $[8,11]$.

\section{Diagnosis}

The most common diagnostic method is a Giemsa stain of the blood smear, where the blue-colored extra or intra-erythrocytic bacilli or coco-bacilli can be observed. Bartonella bacilliformis can parasitize $100 \%$ of the erythrocytes $[1,37]$. Unfortunately, in places that lack good training in this diagnostic technique, the sensitivity can be as low as 36\% [56].

Optimal growth of bacteria of the Bartonella genus is obtained in media containing 5\% rabbit or sheep blood incubated in $5 \% \mathrm{CO}_{2}$. The optimal incubation temperature ranges between $25^{\circ} \mathrm{C}$ and $37^{\circ} \mathrm{C}$. However, B. bacilliformis does not require $5 \% \mathrm{CO}_{2}$, and it is more easily isolated than any other species $[1,57]$. Colonies are small, translucent, and do not produce hemolysis in the blood agar $[1,3,11]$. 
Table 2. Clinical presentation of the eruptive phase of Bartonellosis (Peruvian Wart)

\begin{tabular}{lcc}
\hline & $\begin{array}{c}\text { Maguiña C. } \\
(\mathbf{1 9 6 9 - 1 9 9 2 )} \\
(\mathbf{n = 7 7 )}\end{array}$ & $\begin{array}{c}\text { Rupay J. } \\
(\mathbf{2 0 0 2}) \\
(\mathbf{n = 1 1 1})\end{array}$ \\
\hline Symptoms & & \\
Bleeding of the eruption & $66.2 \%$ & \\
Fever & $57.1 \%$ & \\
Malaise & $53.3 \%$ & \\
Arthralgias & $46.8 \%$ & \\
Signs & & \\
Miliary eruption & $68.8 \%$ & $59.5 \%$ \\
Nodular eruption & $57.1 \%$ & $30.2 \%$ \\
"Mular" eruption & $49.4 \%$ & $10.3 \%$ \\
\hline
\end{tabular}

In Peru, the most common serologic methods are the immunoblot and the indirect immunofluorescence assay (IFA), with a sensitivity of $82 \%$ in acute patients, a positive predictive value of $89 \%$ in endemic areas and a positive predictive value of $45 \%$ during outbreaks [58]. Using irradiated colonies in Vero cells plus an IFA, there is an improvement of sensitivity to $88 \%$ and of specificity to $95 \%$, as was demonstrated during the Cusco outbreak [41]. A positive predictive value of $89 \%$ was obtained with this method in an endemic area [59]. Rapid PCR assays were used during the Cusco outbreak, and they helped with the confirmation of the initial cases; however, there are no studies about their sensitivity or specificity $[41,60]$.

During the eruptive phase, the diagnostic choices are the biopsy of the lesion and Western Blots of sera. The histopathology of Peruvian Wart must be differentiated from that of skin cancers, hemangiomas, pyogenic granulomas, and Bacillary Angiomatosis $[1,8]$.

\section{Treatment}

In an in vitro analysis, B. bacilliformis showed susceptibility to most beta-lactams, rifampin, erythromycin, macrolides, tetracycline, quinolones, and chloramphenicol. However, the bacterium is resistant to vancomycin, clindamycin, and aminoglycosides [61]. During the last decade, some cases of $B$. bacilliformis resistant to chloramphenicol have been reported $[41,61]$. Because of this, a new Peruvian therapeutic scheme was recently formulated.

According to the Health Ministry of Peru [46], the acute phase of Bartonellosis without complications should be treated with ciprofloxacin for 10 days. For patients younger than 7 years old, the scheme is 10 $\mathrm{mg} / \mathrm{kg}$ divided into two doses, for patients between 7 and 14 years old the dose is $250 \mathrm{mg} \mathrm{BID}$, and for patients older than 14 years old the dose is $500 \mathrm{mg}$ BID. An alternative treatment is chloramphenicol $50 \mathrm{mg} /$ $\mathrm{kg} /$ day, divided into four doses during the first three days, and then $25 \mathrm{mg} / \mathrm{kg} /$ day until completing 14 days of treatment. If a complication occurs during the acute phase, and the patient is not pregnant, then the treatment would be ciprofloxacin and ceftriaxone or ceftazidime during 10 days. If a pregnant patient has complicated acute Bartonellosis, the treatment is chloramphenicol $50-100 \mathrm{mg} / \mathrm{kg} / \mathrm{day}$, divided into four doses, plus penicillin G 50,000-100,000 IU/kg/day divided into 4 or 6 doses, for 14 days. The treatment schemes based on ciprofloxacin and chloramphenicol have the advantage of also covering the possibility of Salmonella sp. and Haemophilus influenzae in the pediatric population $[1,8,44,46]$. The monitoring of the patients during the treatment is based on the clinical features and on the blood smears obtained on the $3^{\text {rd }}$, $7^{\text {th }}, 14^{\text {th }}$ and $21^{\text {st }}$ day after the beginning of the treatment. The use of a shorter treatment regime has 
been associated with increased mortality $(R R=6.58$, $\mathrm{p}<0.001)$ [41].

A complication should be suspected if there is no improvement within the first 72 hours of treatment. In case of concomitant infection, the patient has to be treated according to the standardized treatment $[8,46]$. There are case reports of the beneficial effect of using corticoids, such as dexamethasone $(0.5-1 \mathrm{mg} / \mathrm{kg} /$ day for three days) in neurobartonellosis, respiratory distress syndrome, coagulopathy, and/or moderate to severe pericarditis [46,62]. However, no control trials have been done. Red blood cell transfusions in the amount of $10-20 \mathrm{~mL} / \mathrm{kg}$ are given when the hematocrit is less than $20 \%$ [46]. In case of severe pericardial tamponade, a pericardiectomy is done.

The recommended treatment for the eruptive phase is rifampin $10 \mathrm{mg} / \mathrm{kg} /$ day QID during 14 to 21 days. Otherwise, azithromycin, erythromycin, or ciprofloxacin can be given for 7 to 14 days [1,46]. In this phase, chloramphenicol and penicillin are not useful $[1,46]$.

\section{Conclusions}

Carrion's Disease is an endemic and reemerging disease in Peru, Ecuador and Colombia, characterized by a unique pattern of two different clinical presentations that require different approaches. The pathogenesis and immunological aspects of this disease are not well understood yet.

Carrion's Disease constitutes a health problem in Peru because its epidemiology has changed and it is now affecting new habitats, which were previously unrecognized. Although the mortality among inpatients is currently low, the mortality remains variable in new affected areas. During the outbreaks and in endemic areas, the pediatric population has been the most commonly affected.

In the pediatric population the acute phase is characterized by symptoms like fever, hyporexia, malaise, and nausea or vomiting; the main signs are pallor, hepatomegaly, lymph node enlargement, cardiac murmur, and jaundice. Arthralgias and weight loss are commonly described. The morbidity and mortality of the acute phase are variable, because of superimposed infections like typhoid fever, pneumococcal pneumonia, pneumocystis pneumonia, and tuberculosis; or due to respiratory, cardiovascular, neurological, or gastrointestinal complications. The eruptive phase is characterized by eruptive nodes (which commonly bleed) and arthralgias, and currently mortality is extremely rare. This phase must be differentiated from Bacillary Angiomatosis and Kaposi's Sarcoma.

For decades, the diagnosis has been based on blood culture and on direct observation of the bacilli in a blood smear. Western Blot has good sensitivity and specificity during the eruptive phase. However, well-standardized serological or molecular assays are still not available, and they would be difficult to administer in poor rural areas. There are national standardized treatments, based on ciprofloxacin for the acute phase and rifampin for the eruptive phase.

\section{References}

1. Maguiña C. Bartonellosis o Enfermedad de Carrión, nuevos aspectos de una vieja enfermedad. A.F.A Editores Importadores SA, Lima-Peru, 1998.

2. Maguiña C., Gotuzzo E. Bartonellosis: new and old. Infect Dis Clin North Am 2000; 14:1-22.

3. Maguiña C., Garcia P.J., Gotuzzo E., et al. Bartonellosis (Carrion's Disease) in the modern era. CID 2001;33:772-9.

4. Bass J.W., Vincent J.M., Person D.A. The expanding spectrum of Bartonella infections: Bartonellosis and Trench Fever. Ped Infect Dis J 1997;16(1): 2-10.

5. Neves P., Cintra M.L., Uthida-Tanaka A.M., et al. What do we (not) know about the Human Bartonelloses?. Braz J Inf Dis 2003;7(1):1-6.

6. Allison M.J., Pezzia A., Gerszten E., et al. A case of Carrion's disease associated with human sacrificed from the Huari culture of southern Peru. Am J Phys Anthropol 1985;41:295-300.

7. Perez J.E., Ogusuko E. Historical aspects of the vectors of Bartonellosis and Leishmaniasis in Peru. Bol Dir Malariol y San Amb 1995;35:277-94.

8. Pachas P. La Bartonelosis en el Perú. Módulos Técnicos, Oficina General de Epidemiología - Instituto Nacional de Salud. Lima, 2000.

9. Perez J.E., Ogusuko E. Historical aspects of the vectors of Bartonellosis and Leishmaniasis in Peru. Bol Dir Malariol y San Amb 1995;35:277-94. 
10. Garcia-Caceres U., Garcia F.U. Bartonellosis: an immunodepressive disease and the life of Daniel Alcides Carrion. Am J Clin Pathol 1991;95(Suppl. 1):58-66.

11. Herrer A. Epidemiología de la Verruga Peruana. Edited by Gonzales-Mugaburu, Lima-Peru, 1990.

12. Yasuji A., Rumbea J., Knobloch J., et al. Bartonellosis in Ecuador: serosurvey and current status of cutaneous verrucous disease. Am J Trop Med Hyg 1997;57(2):174-9.

13. Solano L., Morocho L., Bueno C., et al. Investigación de Bartonelosis en el valle de Puchka, Provincia de Huari, Ancash-Perú. Rev Per Med Trop UNMSM 1993;7(1):13-25.

14. Schultz M.G. Daniel Carrion's experiment. N Engl J Med 1968;278:1323-6.

15. Minnick M., Mitchell S., McAllister S. Cell entry and the pathogenesis of Bartonella infections. Trends in Microbiology 1996;4(9):342-6.

16. Krueger C.M., Marks K.L., Ihler G.M. Physical map of the Bartonella bacilliformis genome. J Bacteriol 1995;177(24):7271-4.

17. Mitchell S., Minnick M. Characterization of a two-gene locus from Bartonella bacilliformis associated with the ability to invade human erythrocytes. Infect Immun 1995;63(4):1552-62.

18. Breitschwerdt E.B., Kordick D.L. Bartonella infection in animals: carriership, reservoir potential, pathogenicity, and zoonotic potential for human infection. Clin Microbiol Rev 2000;13(3):428-38.

19. Birtles R., Fry N., Ventosilla P., et al. Identification of $B$. bacilliformis genotypes and their relevance to epidemiological investigation of human bartonellosis. J Clin Microbiol 2002;40(10):3606-12.

20. Dehio C. Bartonella interactions with endothelial cells and erythrocytes. Trends in Microbiology 2001; 9(6):279-85.

21. Buckles E., McGinnis H. Interaction of Bartonella bacilliformis with human erythrocyte membrane proteins. Microbial Pathogenesis 2000;29:165-74.

22. Rolain J.M., Novelli S., Ventosilla P., et al. Immunofluorescence detection of Bartonella bacilliformis flagella in vitro and in vivo in human red blood cells as viewed by laser confocal microscope. Ann NY Acad Sci 2003;990:581-4.

23. Hendrix L.R. Contact-dependent hemolytic activity distinct from deforming activity of Bartonella bacilliformis. FEMS Microbiol Lett 2000;182:199-224.

24. Birtles J.B., Harrison T.G., Saunders N.A., Molyneux D.H. Proposal to unify the genera Grahamella and Bartonella, with descriptions of Bartonella talpae comb. nov., Bartonella peromysci comb. nov., and three species, Bartonella grahamii sp. nov., Bartonella taylorii sp. nov., and Bartonella doshiae sp. nov. Int J Syst Bacteriol 1995;45:1-8.
25. Zeaiter Z., Liang Z., Raoult D. Genetic classification and differentiation of Bartonella species based on comparison of partial ftsZ gene sequences. J Clin Microb 2002;40(10):3641-7.

26. Dehio C.H., Sander A. Emerging Bartonellosis. Microbiology Today 2003;30:168-9.

27. Huarcaya E., Maguiña C., Merello J., et al. A Prospective study of Cat Scratch Disease in Lima-Peru. Rev Inst Med Trop S Paulo 2002;44(6):325-30.

28. Cáceres A. Distribución geográfica de Lutzomyia verrucarum (Townsend, 1913) (Diptera, Phychodidae, Phlebotominae), vector de la Bartonellosis humana en el Peru. Rev Inst Med Trop S Paulo 1993;35(6):485-90.

29. Herrer A., Christensen H.A. Implication of Phlebotomus sandflies as vectors of bartonellosis and leishmaniasis as early as 1764 . Science $\mathbf{1 9 7 5 ; 1 9 0 : 1 5 4 - 5 . ~}$

30. Villaseca P., Padilla C., Ventura G., et al. Importancia de la Lytzomyia peruensis en la transmisión de la enfermedad de Carrión en el Valle Sagrado de los Incas, UrubambaCuzco, Perú. Rev Med Exp 1999;25:28-30.

31. Cáceres A., Galati E., Le Pont F., et al. Possible role of Lutzomyia maranonensis and Lutzomyia robusta (Diptera, Phychodidae, Phlebotominae) as vectors of human bartonellosis in three provinces of region Nor Oriental del Marañon, Peru. Rev Inst Med Trop S Paulo 1997;39(1):51-2.

32. Samper B., Montoya J. Estudios bacteriológicos de un germen aislado en una epidemia de Bartonelosis en el departamento de Nariño (Colombia). Rev Med Bogota 1970;2:123-4.

33. Sardan Y., Caycho O. Bartonelosis en el departamento de Huanuco. Bol Soc Per Med Interna 1999;12(4):213-4.

34. Maco V., Maguiña C., Tirado A., et al. Carrion's Disease (Bartonellosis) in the high forest of Peru: report $\mathrm{f}$ the first case confirmed with histopathology. Rev Inst Med Trop S Paulo 2004; (in press).

35. Montoya M., Maguiña C., Vigo B., et al. Bartonellosis en el valle sagrado de los Incas (Cusco). Bol Soc Per Med Interna 1998; 11:170-6.

36. Chinga E., Huarcaya E., Nasarre C., et. al. The influence of climate on the epidemiology of Bartonellosis in Ancash, Peru. Trans R Soc Trop Med Hyg 2004;(in press).

37. Sánchez P. Algunos aspectos epidemiológicos de la enfermedad de Carrión en el Perú. Rev Peru Epidemiol 1986;1(1):5-15.

38. Soláno L. Investigación de anticuerpos anti-bartonella en la enfermedad de Carrión o Bartonelosis Humana. Rev Peru Epidemiol 1986; 1(1):27-8.

39. Broncano V.F., Tuya R.N. Epidemiología de la Bartonellosis humana UTES-Caraz, 1992. [Abstract]. In: III Peruvian Congress of Tropical and Infectious Diseases, 1993. 
40. Chamberlin J., Laughlin L.W., Romero S., et al. Epidemiology of endemic Bartonella bacilliformis: a prospective cohort study in a Peruvian mountain valley community. J Infect Dis 2002;186(7):983-90.

41. Montoya M. Caracteristicas clinicas, epidemiologicas, laboratoriales y factores de riesgo en pacientes con bartonellosis aguda complicada. Magister Thesis, Universidad Peruana Cayetano Heredia, 2003.

42. Patruco R. Estudio de los parámetros inmunológicos en pacientes portadores de la Enfermedad de Carrión. Diagnostico 1983;12(4):138-44.

43. Contreras G. Historia y aportes al conocimiento de la inmunológica en la Veruga Peruana. Presentation for the incorporation to the National Academy of Medicine, Peru, 1994.

44. Espinoza R. Bartonellosis aguda en niños: estudio retrospectivo en el Instituto Nacional de Salud del Niño, 1976-1985. Bachelor thesis, UPCH, 1987.

45. Reynaferje C., Ramos J. The hemolytic anemia of human bartonellosis. Blood 1961; 17:562-78.

46. MINSA. Normas técnicas para el diagnostico y atención curativa de la Bartonellosis o Enfermedad de Carrión en el Perú. Ministerio de Salud (MINSA), Lima, 2003.

47. Díaz C., Ortiz F., Murga de Ortiz H. Bartonelosis o Enfermedad de Carrión. Rev Hosp Niño 1971;23(127): 116-24.

48. Oliveros M., Alva J., Polanco R., et. al. Enfermedad de Carrión en Niños. Rev Hosp Niño 1967;29(109): 1926.

49. Tuya RN, Broncano VF, Granados HD. Bartonelosis aguda y óbito fetal. A propósito de dos casos. Laborat-Acta 1994;6(1):15-6.

50. Tuya R.N., Broncano V.F., Enríquez C.A. Transmisión transplacentaria de Bartonellosis aguda, a propósito de un caso. Laborat-Acta 1994;6(2):43-5.

51. Tarazona A., Solórzano N., Chiroque J., et. al. Transmisión vertical de Bartonelosis Humana, reporte de un caso (Abstract). In: VIII Peruvian Congress of Tropical and Infectious Diseases, Lima-Peru, 2003.

52. LeBoit P.E., Berger T.G., Egbert B.M., et al. Bacillary Angiomatosis, the histopahology and differential diagnostic of a pseudoneoplastic infection in patients with human immunodeficiency virus disease. Am J Surg Pathol 1989;13:909-20.

53. Verma A., Davis G., Ihler G.M. Formation of stress fibers in human endothelial cells infected with Bartonella bacilliformis is associated with altered morphology, impaired migration, and defects in cell morphogenesis. Cellular Microbiology 2001;3(3):169-80.

54. Arias-Stella J., Bravo-Puccio F. Angiomatosis Bacilar en el Peru, una nueva forma de Bartonelosis que es necesario diferenciar de la Verruga Peruana. Fol Dermatol Per 1996; 7:31-6.
55. Arias-Stella J., Lieberman P.H., Garcia-Caceres U., et al. Veruga Peruana mimicking malignant neoplasms. Am J Dermatopathol 1987;9:279-91.

56. Araujo D., Caleron G., Vera-de-Coronel V., et al. Bartonella bacilliformis in patients proceeding from the south of the Manabi province. Rev Univ Guayaquil 1987;3(69):1-6.

57. Slater L.N., Welch D.F., Helsen D., Coody D.W. A new recognized fastidious Gram-negative pathogen as a cause of fever and bacteremia. N Engl J Med 1992;323:1587-93.

58. Knobloch J., Solano L., Alvarez O., et al. Antibodies to Bartonella bacilliformis as determined by fluorescence antibody test, indirect haemagglutination, and ELISA. Trop Med Parasitol 1985;36:183-5.

59. Chamberlin J., Laughlin L., Gordon S., et al. Serodiagnosis of Bartonella bacilliformis infection by Indirect Fluorescence Antibody Assay: test development and application to a population in an area of Bartonellosis endemicity. J Clin Microb 2000;38(11):4269-71.

60. Huarcaya E., Infante B., Maguiña C., et al. Identificación de Bartonella sp. mediante reacción en cadena de la polimerasa y métodos microbiológicos. Diagnostico 2003;42(4):151-3.

61. Sobraques M., Maurin M., Birtles R., et al. In vitro susceptibilities of four Bartonella bacilliformis strains to 30 antibiotic compounds. Antimicrob agent Chemothera 1999;43(8):2090-2.

62. Franco V. Complicaciones cardiovasculares en la fase aguda de la bartonellosis en el Hospital Nacional Cayetano Heredia entre los años 1987-1997. Bachelor Thesis, Universidad Peruana Cayetano Heredia, 1998. 